\title{
America and the Swiss Stock Exchange: An Intraday Analysis
}

\author{
Claudio Loderer* and Marc-André Mittermayer**
}

JEL-Classification: G10, G14, G15

Keywords: Switzerland, U.S., equity, linkages, economic news, Wall Street open, return volatility, trading volume

Financial analysts and the media often argue that the Swiss stock market reacts to news from the U.S., including the opening of Wall Street. On July 31, 2002, for example, the most widely circulated daily newspaper Neue Zürcher Zeitung reported that worse-than-expected economic data and a subsequent weak opening of Wall Street depressed the Swiss stock market. We investigate whether and in what sense this dependence can actually be observed. We want to know whether the two markets are correlated, whether SWX traders respond to information that is relevant to Wall Street, and whether there is any evidence that the SWX lags Wall Street.

More specifically, we examine how the release of U.S. macroeconomic news that is relevant to the American stock market (Wall Street for simplicity) affects stock return volatility and trading volume on the SWX. Moreover, we study how the correlation between the two markets evolves over time following the opening of Wall Street until the close of the SWX. We want to know how important this correlation is and whether there is any evidence that the Swiss market trails Wall Street. We also explore how return volatility and trading volume on the SWX change immediately preceding the Wall Street open and thereafter.

* Institut für Finanzmanagement, Universität Bern, 3012 Bern, Switzerland. Corresponding author (claudio.loderer@ifm.unibe.ch). We are grateful to Antoinette Hunziker-Ebneter, former CEO, and Christian Egger, head of the database group of the SWX for providing the high-frequency data used in this study. We also benefited from the comments of two anonymous referees. Furthermore, we wish to thank K. Schmidheiny for his suggestions and David Belz as well as Andrea Neves for the great editorial help.

** Institut für Wirtschaftsinformatik, Universität Bern, 3012 Bern, Switzerland. 
Previous studies have pursued similar lines of inquiry. Some examine co-movement among international equity markets, asking among other things whether common fundamental factors or contagion effects might cause that correlation. ${ }^{1}$ Other studies analyze the intraday behavior of stock return volatility. ${ }^{2}$ And other studies yet investigate the intraday impact of macroeconomic news releases, particularly those related to the U.S. economy. ${ }^{3}$

Our investigation is similar in principle to those conducted by BECKER, Finnerty, and Friedman (1995) and Ederington and Lee (1993 and 1996). Becker, Finnerty, and Friedman, for example, examine the impact of macroeconomic news releases using transaction prices closest to the half-hour of every trading day for FTSE 100 and S\&P 500 futures contracts from July 1, 1986 to December 28, 1990. They find that FTSE return volatilities jump significantly right after U.S. macroeconomic announcements about employment, retail sales, and the consumer price index. In contrast, the U.K. volatility corresponding to the opening of U.S. markets is no higher than what would be predicted by the traditional U-shaped intraday return volatility pattern. These results contradict the previous study by KING and WADHWANI (1990) that examines intraday FTSE spot index values from July 1 to October 13, 1987. This paper finds low volatility surrounding U.S. announcements coupled with heightened price movements corresponding to the opening of the U.S. stock market.

According to our results, return volatility and trading volume on the Swiss stock exchange more than triple at the time of release of U.S. macroeconomic news relevant to Wall Street, and stay higher until the end of the trading day. However, both return volatility and trading volume dip right before Wall Street opens. It appears as if Swiss traders wait to see how Wall Street opens before resuming their trades. Thereafter return volatility and trading volume go back to normal patterns. There is also evidence that stock price changes on the SWX are closely related to what happens on Wall Street. And results indicate that the SWX trails Wall Street somewhat, particularly at the time of the Wall Street

1 That literature includes Eun and Shim (1989), Hamao, Masulis, and Ng (1990), King and Wadhwani (1990), Lin, Engle, and Ito (1994), Susmel and Engle (1994), Oertmann (1995), Karolyi and Stulz (1996),

2 See Harris (1986), Admati and Pfleiderer (1988), Jain and Joh (1988), Lockwood and Linn (1990), and Chan, Chan, and Karolyi (1991).

3 See McQueen and Roley (1993), Ederington and Lee (1993 and 1996), Becker, Finnerty, and Friedman (1995), Jones, Lamont, and Lumsdaine (1998), Li and Engle (1998), ConNOLLY and WANG (2003). The literature on the impact of macroeconomic announcements is considerable. For additional references, see, among others, De goeij and MARQUering (2004), Fornari (2004), and Poitras (2004). 
open. This lagged relation is too weak, however, to imply a profitable investment strategy.

The paper is structured as follows. The first section presents the hypotheses and the methods used to test them. Section 2 describes the data. Section 3 discusses the results and Section 4 offers conclusions.

\section{Hypotheses and Test Methodology}

If the SWX was somehow driven by Wall Street, it would react to the same news and respond to what actually happens there. In particular, the Wall Street open would induce a prolonged increase both in volatility and trading volume on the SWX. Following is an explanation of these hypotheses in more detail and a discussion of how we intend to test them.

\subsection{Hypotheses}

We begin our investigation with an examination of the correlation between Wall Street and the SWX from the Wall Street open to the SWX close. Based on the ties between the Swiss and the U.S. economies, that correlation should be positive. What we are interested in is whether, as asserted by the financial press, there is also a positive lagged correlation. That should be the case particularly right after the Wall Street open since that event would likely release information that Swiss traders allegedly have been waiting for. That is the first proposition we want to test.

The second proposition follows Becker, Finnerty, and Friedman (1995) and Ederington and Lee (1993 and 1996). Accordingly, the disclosure of major macroeconomic news in the U.S. should lead to a significant increase in stock return volatility on the SWX.

If the macroeconomic news disclosure is significant, it should introduce uncertainty that could take time to be resolved. Thus, the third proposition we examine is whether major macroeconomic news releases in the U.S. have a prolonged impact on return volatility.

The fourth testable proposition is that the Wall Street open induces an increase in stock return volatility. Theoretical and empirical arguments buttress the prediction of a volatility spike following that event. KING and WADHWANI (1990), for instance, predict that in a non-fully-revealing equilibrium there should be a price jump in all other markets when one particular market reopens. Consistent with that, they observe that the volatility of prices in London rises just 
after the New York opening. If there is uncertainty about the Wall Street open, however, return volatility should rise also right before that event. This assertion is based on research documenting an increase in stock return volatility around predictable events such as dividend (Kalay and Loewenstein, 1985) and earnings announcements (PAtell and Wolfson, 1979). We also examine whether the impact of the Wall Street open depends on whether it is preceded by a U.S. macroeconomic disclosure. ${ }^{4}$

The fifth proposition we test is based on FRENCH and RolL's (1986) finding of a volatility increase when traders interact. Accordingly, stock return volatility on the SWX should rise during the time both markets are open, namely from the opening of Wall Street at 3:30 p.m. to the close of the SWX at 4:30 p.m. Swiss time.

Intuitively, the very same propositions should hold also for trading volume. Specifically, trading volume should increase at the time of U.S. macroeconomic announcements, at the time Wall Street opens, and during the time both Wall Street and the SWX are open. We define trading volume as number of shares traded.

\subsection{Test Methodology}

\subsubsection{Correlation Tests}

To test these predictions, we work with continuously compounded returns, $R_{t}^{I}$, defined as follows:

$$
R_{t}^{I}=\ln \left(\frac{P_{t}^{I}}{P_{t-1}^{I}}\right)
$$

where the superscript I denotes the stock index of relevance, the subscript $t$ indicates time of the day, and $P_{t}^{I}$ is the value of the index at time t.

We investigate the correlation between the U.S. and the Swiss stock market by regressing the return on the Swiss Market Index (SMI) against the contemporaneous and lagged returns on the S\&P 500 index. The regression takes the following form:

$$
R_{i j}^{S M I}=\beta_{0}+\beta_{1} R_{i j}^{S \& P}+\beta_{2} R_{i j-1}^{S \& P}+\varepsilon_{i j}, i=1, \ldots, n ; j=1, \ldots, 12 .
$$

4 For a discussion of the impact of the U.S. markets on the SWX, see also RANALDO (2004).

5 The literature on the correlation between trading volume and return volatility is vast. See, for example, Gallant, Rossi, and Tauchen (1992), and Hiemstra and Jones (1993). 
The regression is estimated between 3:30 p.m. and 4:30 p.m. Swiss time for each 5minute interval $j=1, \ldots, 12$ of joint trading across all the days $i$ in the sample period (for details on data, see the next section). The variables are defined as follows:

$R_{i j}^{S M I}=$ the continuously compounded return on the SMI for the 5-minute interval $j$ on day $i$;

$R_{i j}^{S \& P}=$ the continuously compounded return on the S\&P 500 for the 5-minute interval $j$ on day $i$;

$R_{i j-1}^{S \& P}=$ the continuously compounded return on the S\&P 500 for the 5-minute interval $j-1$ on day $i$; and,

$\varepsilon_{i j} \quad=$ a serially uncorrelated, normally distributed error term with zero mean and constant volatility.

We expect the coefficient $\beta_{1}$ associated with the contemporaneous return on the S\&P 500 to be positive. More importantly, if the SWX trails Wall Street, the coefficient $\beta_{2}$ associated with the lagged return on the S\&P 500 should be positive as well. The assumption, of course, is that a 5-minute interval is short enough to capture this relation.

\subsubsection{Tests of Volatility and Trading Volume Changes}

Stock return volatility is defined as the standard deviation (SD) of return during the intraday interval of relevance, $j$, namely as:

$$
S D_{j}^{I}=\sqrt{\frac{1}{(n-1)} \sum_{i=1}^{n}\left(R_{i, j}^{I}-\bar{R}_{j}^{I}\right)^{2}},
$$

where $\mathrm{n}$ is the number of days in the sample, and $\bar{R}_{j}^{I}$ is the average return over the same intraday interval (computed across all days in the sample for the interval in question), and, as before, I denotes the stock index of relevance.

To test our propositions concerning stock return volatility, we need a benchmark telling us what would happen to volatility without the events in question. Our standard of comparison is the intraday U-shaped pattern of volatility theorized by Admati and Pfleiderer (1988) and documented in the U.S. for both stock returns ${ }^{6}$ and average volume of shares traded ${ }^{7}$. According to ADMATI and

6 Wood, McInish, and Ord (1985), Harris (1986), Lockwood and Linn (1990), Chan, Chan, and Karolyi (1991).

7 JAIN and JOH (1988). 
Pfleiderer, U-shaped trading- and price-volatility patterns arise endogenously as a result of the strategic behavior of liquidity traders and informed traders. For example, if many discretionary liquidity traders realize their liquidity demands after the market closes, they will want to satisfy them as soon as the market opens the next day. Similarly, the interval within which many discretionary liquidity traders must trade terminates at the close of a trading day. There will therefore be a tendency for trading to be concentrated at the close, too. Given the presence of discretionary liquidity traders at the open and the close, informed traders will tend to gravitate towards those trading times as well, particularly if their signals are correlated. Competition among informed traders (given correlated signals) will improve the terms of trade of liquidity traders and reinforce their tendency to trade at the open and the close of trading.

For a comparison with the patterns reported in the literature, Figure 1 plots the intraday return volatility on the SMI for the period ranging from January 6 - September 30, 1997. As one can see, the intraday U-shaped volatility pattern observed in the U.S. also exists in Switzerland. Note the clear spike at 2:30 p.m. commensurate with the release of U.S. macroeconomic news. The Swiss Performance Index (SPI), the alternative index for the Swiss stock market studied here, follows a similar pattern.

Consequently, our return volatility tests take the form of a regression with the following specification:

$$
\begin{aligned}
S D_{t}^{I}= & \gamma_{0}+\gamma_{1} \times t+\gamma_{2} \times t^{2}+\gamma_{3} \times D_{\text {macro }}^{I} \\
& +\gamma_{4} \times D_{\text {tot }}^{I}+\gamma_{5} \times D_{W S \text { Sopen }}^{I}+\gamma_{6} \times D_{\text {overlap }}^{I}+\varepsilon_{t}^{I}
\end{aligned}
$$

where

$t \quad=$ time elapsed from the first intraday return on the index in question;

$D_{\text {macro }}^{I}=$ a binary variable equal to 1 during the first 10 minutes following the macroeconomic news release, and equal to 0 otherwise;

$D_{t o t}^{I} \quad=$ a binary variable equal to 1 from the time of the macroeconomic news release to the SWX close, and equal to 0 otherwise;

$D_{W S \text { sopen }}^{I}=$ a binary variable equal to 1 during the 10 minutes preceding the Wall Street open, and equal to 0 otherwise;

$D_{\text {overlap }}^{I}=$ a binary variable equal to 1 from the Wall Street open to the SWX close, and equal to 0 otherwise; and,

$\varepsilon_{t} \quad=$ a serially uncorrelated, normally distributed error term with zero mean and constant volatility. 
Figure 1: Intraday SMI-return Volatility

The graph plots the average standard deviation of returns on the SMI during various 5-minute intervals of the day. Period: 1.6.1997-9.30.1997.

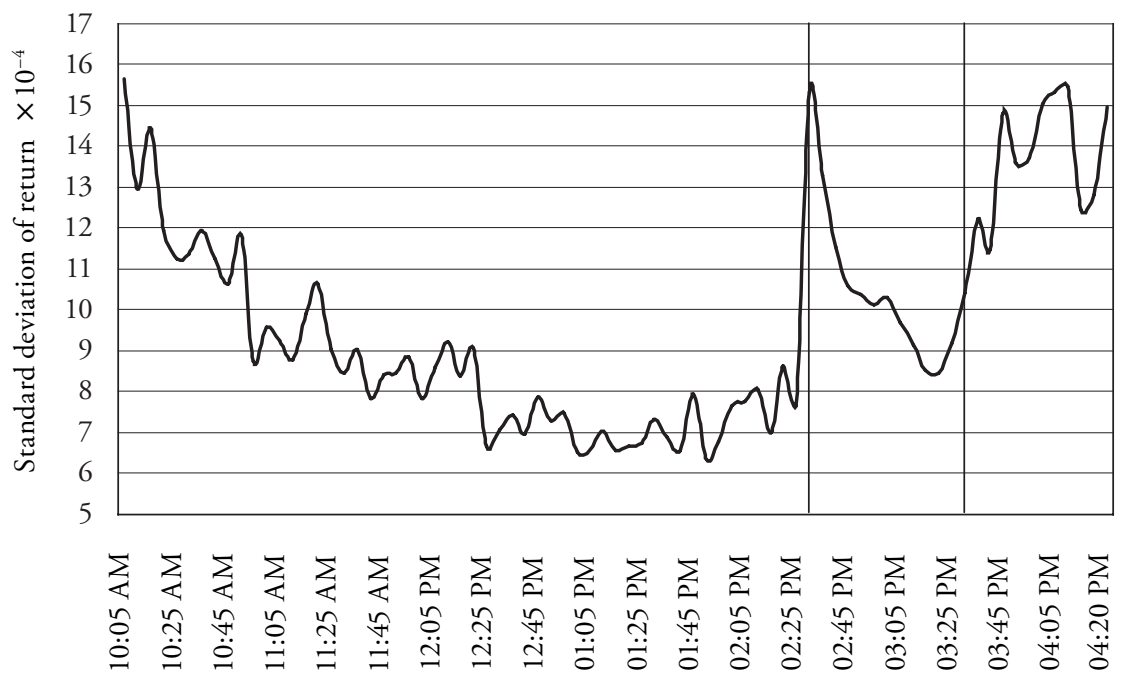

Central European time (5-minute intervals)

The first two arguments in the regression equation involve time and describe a U-shaped intraday volatility pattern. As we just discussed, all the other variables, except for the disturbance term, are binary variables that define a given time interval. We use this regression equation to test our remaining propositions, namely:

a. $D_{\text {macro }}^{I}$ measures possible volatility changes during the 10 minutes immediately following major U.S. macro announcements. As explained below, all the announcements we examine are made at 2:30 p.m. Swiss time (8:30 a.m. Eastern Standard Time). ${ }^{8}$ Based on what we said, this variable should have a positive coefficient;

b. $D_{t o t}^{I}$ captures possible volatility increases from the time of major U.S. macro news releases to the close of trading on the SWX. This variable should have a positive coefficient;

8 In fact, 9 minutes in the case of the SPI and 10 minutes in that of the SMI. 
c. $D_{\text {WSopen }}^{I}$ captures volatility changes during the 10 minutes leading up to the Wall Street open. The coefficient of this variable should be positive; and,

d. $D_{\text {overlap }}^{I}$ measures the effect of joint trading from the Wall Street opening to the SWX close. As argued above, the coefficient of this variable should be positive as well.

We estimate Equation (4) separately for days with and without major U.S. macro announcements. For the latter days, we should observe the following:

a. In the absence of major macroeconomic announcements, the variable $D_{\text {macro }}^{I}$ should have a coefficient of zero;

b. By the same argument, the variable $D_{t o t}^{I}$ should also have a coefficient of zero;

c. The coefficient associated with $D_{W \text { Wopen }}^{I}$ should be positive, since the Wall Street open is presumably associated with uncertainty regardless whether it is preceded by a macroeconomic announcement or not; and,

$\mathrm{d}$. The coefficient of the variable that identifies the time of joint trading, $D_{\text {overlap }}^{I}$, should also be positive. The rationale is the same as that offered for days with macro disclosures.

In estimating Equation (4), we also examine a specification with an additional dummy variable that identifies the first 10 minutes immediately following the Wall Street open. As it turns out, this specification does not change our main conclusions, which is why we focus on the simpler version reported in Equation (4). The coefficient of the additional binary variable is generally negative, although not always statistically significant in the various samples analyzed.

Besides investigating intraday return volatility patterns, we also examine what happens to trading volume during the time intervals in question. As shown in Figure 2, trading volume follows the same U-shaped pattern as return volatility. We therefore expect volume changes to track changes in return volatility and use the same regression approach to investigate the same predictions. The dependent variable in the regression is the median of the sample distribution of volume traded during a particular time interval of the day across all days in the sample. For convenience, the following table summarizes the hypotheses concerning changes in intraday return volatility and trading volume. 


\section{Figure 2: Intraday Trading Volume}

The graph plots the average number of shares traded in the eight stocks with the largest individual trading volume on the SWX. Trading volume is measured at 5-minute intervals during the day. Period: 1.6.1997-9.30.1997.

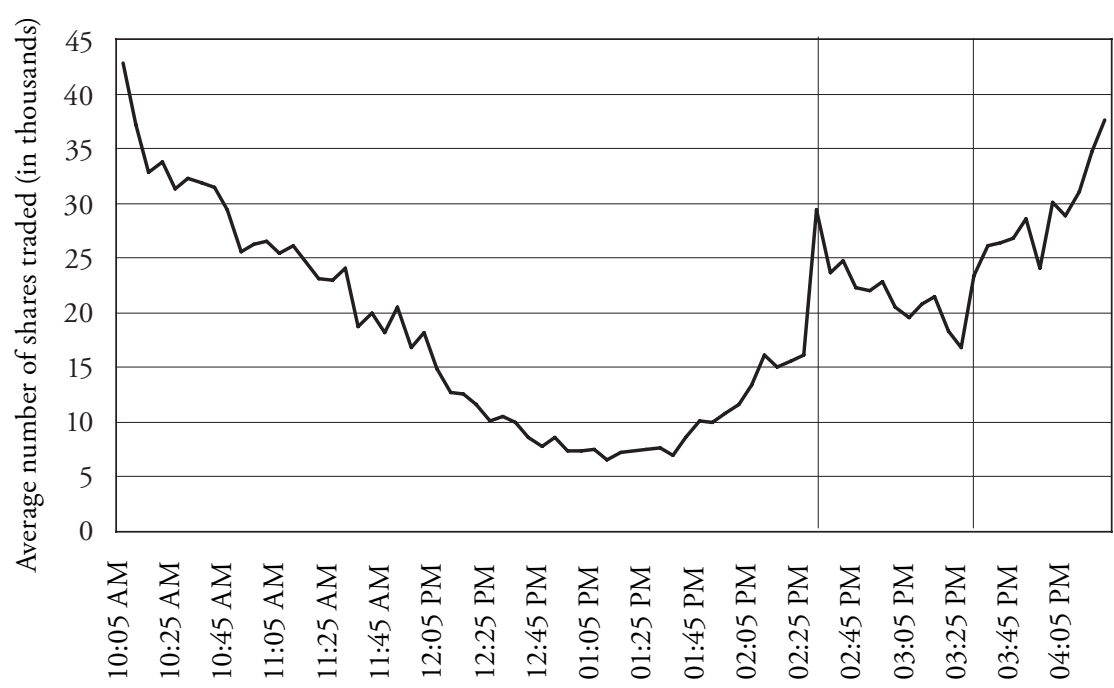

Central European time (5-minute intervals)

\section{Testable Predictions}

\begin{tabular}{|c|c|c|c|c|}
\hline \multirow[t]{4}{*}{ Time of the day } & \multicolumn{2}{|c|}{ Stock return volatility } & \multicolumn{2}{|c|}{ Trading volume } \\
\hline & Days with & Days without & Days with & Days without \\
\hline & macroeconomic & macroeconomic & macroeconomic & macroeconomic \\
\hline & & & & \\
\hline $\begin{array}{l}\text { Ten minutes from U.S. } \\
\text { macro announcement }\end{array}$ & $\gamma_{3}>0$ & $\gamma_{3}=0$ & $\gamma_{3}>0$ & $\gamma_{3}=0$ \\
\hline $\begin{array}{l}\text { From U.S. macro } \\
\text { announcement to SWX close }\end{array}$ & $\gamma_{4}>0$ & $\gamma_{4}=0$ & $\gamma_{4}>0$ & $\gamma_{4}=0$ \\
\hline $\begin{array}{l}\text { Ten minutes } \\
\text { before Wall Street open }\end{array}$ & $\gamma_{5}>0$ & $\gamma_{5}>0$ & $\gamma_{5}>0$ & $\gamma_{5}>0$ \\
\hline $\begin{array}{l}\text { Time of joint Wall Street } \\
\text { and SWX trading }\end{array}$ & $\gamma_{6}>0$ & $\gamma_{6}>0$ & $\gamma_{6}>0$ & $\gamma_{6}>0$ \\
\hline
\end{tabular}




\section{The Data}

To examine the relation between Wall Street and the Swiss Stock Exchange (SWX), we gather intraday stock returns and trading volume. The data cover two adjacent periods: an initial period that spans the dates January 6 - September 30, 1997, and a later period that covers the dates October 2 - June 26, 1998. We use the latter period to confirm the regularities observed during the former. We therefore refer to the former period as the original period and to the latter as the holdout period.

\subsection{The Stock Indices}

The SWX was established in 1995 and represents the first fully automated trading, clearing, and settlement system of the world. Thanks to this automation, trades on the SWX are carried out very quickly. During the period under analysis, the completion of a trade took an average 0.5 seconds, compared to 5 seconds on most other exchanges. According to SWX Factbook of 1998, the SWX was the sixth largest exchange in the world based on its annual trading volume of 0.7 trillion USD. At the end of 1998, 283 domestic and 203 foreign stocks (corresponding to 231 and 193 companies, respectively) were listed on the SWX. At the time of analysis, the SWX opened at $10 \mathrm{a} . \mathrm{m}$. and closed at 4:30 p.m. (Swiss time).

We analyze the Swiss stock market with two alternative indices, the Swiss Performance Index (SPI) and the Swiss Market Index (SMI). The SPI is a dividendcorrected index that covers all domestic firms, except investment firms, listed on the SWX. ${ }^{10}$ The SPI is computed every 3 minutes, starting with a lag of 20 minutes after the opening at 10:00 a.m. The delay is to prevent bias because of thinly traded stocks. In contrast, the SMI is an index that covers around 25 Swiss blue chips and represents $80 \%$ of the total market capitalization of Swiss companies. The analysis of the SMI enables us to focus on the most liquid stocks on the SWX. The SMI is a real-time index, in that it is computed every time the price of one of its component stocks changes. Since it includes only fairly liquid stocks, it is computed from the opening of the SWX with no delay. ${ }^{11}$ Still, to get around the problem of infrequent trading, we ignore the first five minutes of trading and start computing returns from 10:05 a.m. on. The data we received

9 Since August 3, 1998, trading hours have changed several times.

10 In addition to domestic firms, it also includes firms from Liechtenstein.

11 Starting on June 29, 1998, the first SMI price of the day is computed 2 minutes after the start of trading. 
were reported in 5-minute intervals, with no time stamp for the trades reported within those intervals. There is therefore no guarantee that the first trade in these intervals occurs precisely at the beginning of the interval in question and that the last trade is carried out exactly five minutes to the second later. Unlike the SPI, the SMI does not assume dividend reinvestment.

In order to examine the correlation between Wall Street and the SWX, we also compute intraday returns on the S\&P 500 based on data provided by the Futures Industry Institute in Washington, D.C. The S\&P 500 is a value-weighted index covering 500 leading companies in the most representative industries of the U.S. economy. As of the end of 1998, these companies make up about $70 \%$ of the total market capitalization in the U.S. The index is computed four times every minute.

Our return dataset combines contemporaneous observations in the two markets. In compiling it, we ignore cases where such simultaneity does not occur. For instance, we drop the days during which one of the two markets is closed for holidays or Wall Street is open only in the morning. Similarly, we ignore days with an asynchronous switch to daylight saving time in the two countries. As a result, we purge the following days from the database: One day for chronological inconsistencies, 29 days because of missing observations in either of the two countries (holidays, etc.), and 3 days because of other data problems. These deletions yield a total sample of 308 trading days.

Table 1 reports the average intraday returns of the SMI and SPI during the full period ranging from January 6, 1997 to June 26, 1998. Computed over 24 hours, these returns equal $0.182 \%$ for the SPI and $0.176 \%$ for the SMI. The table segments these returns roughly over three periods: the time in which the SWX alone is open; the time in which both the SWX and Wall Street are open; and the time when the SWX is closed. As one can see, very little return accumulates when the SWX trades alone - 6\% of the total average daily return on the SPI and $-21 \%$ of the total average daily return on the SMI. Some return accrues during the time the markets are jointly open - the SPI accumulates $22 \%$ of its total average daily return during that time, and the SMI 14\%. Yet most of the return is earned overnight. During the night, the SPI accrues $72 \%$ of its total daily return, and the SMI 106\%. It looks as if investors, at least uninformed investors, would be better off if they stayed away from trading and simply let returns accumulate over night. 
Table 1: Components of Intraday Returns on the SWX

The table reports average returns on the SPI and the SMI during different periods of the day. Specifically, for the SPI, these periods are defined as follows:

SWX open; Wall Street closed: 10:20 a.m. - 3:50 p.m. Swiss time

SWX and Wall Street both open: 3:50 p.m. - last quote (sometimes up to 1 hour after SWX close) SWX closed:

Yesterday's last quote $-10: 20$ a.m. Swiss time

In contrast, for the SMI, we have the following time intervals:

SWX open; Wall Street closed: 10:05 a.m. - 3:50 p.m. Swiss time

SWX and Wall Street both open: 3:50 p.m. - last quote (sometimes up to 1 hour after SWX close) SWX closed: Yesterday's last quote $-10: 05$ a.m. Swiss time

The sample period is: 1.6.1997-6.26.1998.

\begin{tabular}{lcccc}
\hline Index & $\begin{array}{c}\text { SWX open; Wall } \\
\text { Street closed }\end{array}$ & $\begin{array}{c}\text { SWX and Wall Street } \\
\text { both open }\end{array}$ & SWX closed & Total \\
\hline SPI & $0.011 \%$ & $0.040 \%$ & $0.130 \%$ & $0.182 \%$ \\
& $(6 \%)$ & $(22 \%)$ & $(72 \%)$ & $(100 \%)$ \\
SMI & $-0.037 \%$ & $0.025 \%$ & $0.187 \%$ & $0.176 \%$ \\
& $(-21 \%)$ & $(14 \%)$ & $(106 \%)$ & $(100 \%)$ \\
\hline
\end{tabular}

\subsection{Trading Volume}

We define trading volume as the number of shares traded in the eight stocks with the largest individual trading volume on the SWX..$^{12}$ According to SWX Factbook of 1997, the aggregate volume of these stocks represents an average $70 \%$ of the annual trading volume in Swiss stocks. Our proxy for trading volume is measured at 5-minute intervals. ${ }^{13}$ Volume is extremely high during the first five minutes of trading as well as during the last five minutes. We ignore these two time intervals. The first observations therefore refer to 10:05-10:10 a.m. and the last ones to 4:20-4:25 p.m. of every trading day.

12 The eight stocks in question include the bearer shares of ABB, UBS, and Zürich Versicherungs-Gesellschaft; the registered shares of CS Group, Nestlé, Novartis, and Schweizerische Rückversicherungs-Gesellschaft; and the non-voting bearer shares of Roche.

13 In principle, trades larger than CHF 200,000 can occur off the exchange but must be reported within 30 minutes. Our data include off-exchange trades. 


\subsection{U.S. Macroeconomic News}

The U.S. macroeconomic news examined here is released at 8.30 a.m. Eastern Standard Time by various agencies of the federal administration in the U.S. such as the Bureau of Labor Statistics and the Bureau of the Census. The release dates are always the same and are therefore widely anticipated. For instance, the Employment Report is released the first Friday of every month at 8.30 a.m. Eastern Standard Time. YAHOO Finance rates all macroeconomic releases by importance for the U.S. stock market from A to F. ${ }^{14}$ Table 2 reports the announcement types in the sample, along with the identity of the reporting agency and the reporting time. This paper focuses on announcements with a rating of at least B-. ${ }^{15}$ About one third of the trading days during the sample period have such announcements; we refer to them as days with major macroeconomic announcements. The remaining days are referred to as days without major macroeconomic announcements. By definition, there are macroeconomic announcements on some of these latter days as well (at 8.30 a.m. or later), but they should be relatively unimportant.

Table 2: Macroeconomic Announcements

The table lists the macroeconomic announcements of relevance for our investigation, the time of their release, the ranking of their importance according to YAHOO Finance, and the reporting agency. 8:30 a.m. Eastern Standard Time corresponds to 2:30 p.m. Swiss time. Sample period: 1.6.1997-6.26.1998.

\begin{tabular}{llcl}
\hline $\begin{array}{l}\text { Time (Eastern } \\
\text { Standard Time) }\end{array}$ & Topic of Report & $\begin{array}{c}\text { YAHOO } \\
\text { Finance Rating }\end{array}$ & Reporting Agency \\
\hline 8:30 a.m. & Employment & A & Bureau of Labor Statistics \\
8:30 a.m. & Retail Sales & A- & U.S. Census Bureau \\
8:30 a.m. & Consumer Price Index & B+ & Bureau of Labor Statistics \\
8:30 a.m. & International Trade & B+ & U.S. Census Bureau \\
8:30 a.m. & Durable Goods Orders & B & U.S. Census Bureau \\
8:30 a.m. & Gross Domestic Product & B & Bureau of Economic Analysis \\
8:30 a.m. & Housing Starts & B- & U.S. Census Bureau \\
8:30 a.m. & Producer Price Index & B- & Bureau of Labor Statistics \\
\hline
\end{tabular}

14 URL: biz.yahoo.com/c/terms/terms.html.

15 In the meantime, International Trade seems to have been downgraded to $\mathrm{C}+$. 
As mentioned above, all these announcements are made at 8:30 a.m. Eastern Standard Time (EST), one hour before the main U.S. stock exchanges (NYSE, AMEX, and NASDAQ) open. ${ }^{16}$ The release time corresponds to 2:30 p.m. Swiss time. Becker, Finnerty, and Friedman (1995) focus on the same announcements, with the exception that they ignore those relating to gross domestic product. ${ }^{17}$ Their study yields a ranking of importance that differs from the one reported here. In particular, they find that releases concerning employment and retail sales have no significant impact on the S\&P 500 futures returns; in contrast, YAHOO Finance assigns those two announcements the highest ranking. Since the ranking of major macroeconomic announcements by type is immaterial for our purposes, this inconsistency is of no concern.

\section{Empirical Results}

This section presents the results of our empirical analysis. As mentioned above, we start with the so-called original sample (January 6 - September 30, 1997) and then replicate the investigation with the holdout sample (October $2-$ June 26, 1998).

\subsection{Original Sample}

3.1.1 Intraday Correlation between Wall Street and the Swiss Stock Exchange

Table 3 looks at the correlation between the two markets during the time of joint trading. We show the results of regressing the SMI return during a particular 5minute interval against the contemporaneous return and the lagged return on the S\&P 500 [Equation (2) above]. The various rows in the table show the results of this regression for each of the twelve 5-minute intervals during the time both Wall Street and the SWX are trading. The $t$-statistics associated with the regression coefficients are based on standard errors corrected for heteroskedasticity and autocorrelation according to Newey and West.

The evidence is consistent in principle with the view that the two markets are closely related. Nevertheless, this contention has to be properly qualified. First, the coefficient of the contemporaneous S\&P 500 return is indeed highly significant and generally larger than 0.8 . Second, however, this relation is fairly noisy,

16 There are news releases also at 10 a.m. EST, but they are relatively much less frequent.

17 They include the releases of Leading Indicators and of Non-farm Payrolls instead. 
since the adjusted $R^{2}$ of the regression is mostly below $50 \%$. That means that $50 \%$ of the volatility of the Swiss market is due to impulses other than those reflected in the S\&P 500 index. Third, right after the Wall Street open, SWX traders seem to be somewhat confused. The explanatory power of the regression during the first 5 minutes of contemporaneous trading is weaker than during the rest of the day (except for the last minutes of the day). To be honest, this could also occur because of infrequent trading at the start of Wall Street. ${ }^{18}$ And fourth, the lagged return on the S\&P 500 is often negative although generally not significantly different from zero. The exception is during the first 15 minutes of joint trading and from 4:05 to 4:10 p.m. Swiss time. A lagged relation could also be the result of infrequent trading. The problem with this interpretation is that it does not imply a negative relation, nor can it explain why the SWX lags Wall Street.

A significant lagged coefficient confirms in principle the claim that the SWX takes its clues from Wall Street. However, unlike what we hypothesized, the relation is not positive but negative, meaning that the SWX has to correct its previous contemporaneous reaction. Consequently, it looks as if the SWX overreacts to Wall Street. Yet the value of the coefficients indicates that the overreaction is moderate. Specifically, from 3:35 to 3:40, the contemporaneous coefficient is 0.586 , more than twice the absolute value of the lagged coefficient $(-0.179)$. From $3: 40$ to $3: 45$, the contemporaneous coefficient grows to 0.669 and is almost six times larger in absolute value than the lagged coefficient of -0.115 . It would be difficult to design a trading strategy that takes advantage of this regularity. One could, for example, short the SMI five minutes after the S\&P 500 has increased. The problem with this strategy is that, given the economically rather tenuous lagged relation, it is both risky (the adjustment could easily be swamped by the contemporaneous relation with the S\&P 500) and costly (transaction costs could easily exceed the expected gross benefits). Still, the finding of a significantly negative lagged relation, weak as it may be, does support the contention that the SWX is driven in part by what happens on Wall Street. We replicated the analysis by adding the 5-minute return on the S\&P 500 lagged 10 minutes. The results do not change. ${ }^{19}$

18 According to Stoll and Whaley (1990), even S\&P 500 stocks take an average 5 to 7 minutes to start trading.

19 We also repeated the analysis by replacing the SMI with the SPI, an index that includes firms that are much less frequently traded. As pointed out above, we measure SPI returns every 3 as opposed to every 5 minutes. The lagged relation between the SPI and the S\&P 500 is still there, but it is weaker than what we observe for the SMI. It could be that the average firm in the SPI is less sensitive to what happens on Wall Street. 


\section{Table 3: Intraday Relations between Returns on the SMI and the S\&P 500}

The table reports the results of estimating the following regressions of intraday SMI returns against contemporaneous and lagged S\&P 500 returns:

$$
R_{i j}^{S M I}=\beta_{0}+\beta_{1} R_{i j}^{S \& P}+\beta_{2} R_{i j-1}^{S \& P}+\varepsilon_{i j}, i=1, \ldots, 308 ; j=1, \ldots, 12,
$$

where subscript $i$ refers to a given day during the sample period and subscript $j$ denotes a given 5minute interval. The regression is estimated for each 5-minute interval of joint trading between 3:30 p.m. and 4:30 p.m. across all days in the sample period. The variables are defined as follows:

$R_{i j}^{S M I}=$ the continuously compounded return on the SMI for the 5 -minute interval $j$ on day $i$;

$R_{i j}^{S \& P}=$ the continuously compounded return on the S\&P 500 for the 5 -minute interval $j$ on day $i$; $R_{i j-1}^{S \& P}=$ the continuously compounded return on the S\&P 500 for the 5 -minute interval $j-1$ on day $i$; and,

$\varepsilon_{i j} \quad=$ a serially uncorrelated, normally distributed error term with zero mean and constant volatility.

The table reports estimated regression coefficients and (in parentheses) the associated $t$-statistics (on the basis of standard errors corrected for heteroskedasticity and autocorrelation according to Newey and West).

\begin{tabular}{ccccc}
\hline Time interval & $\beta_{0}$ & $\beta_{1}$ & $\beta_{2}$ & Adjusted $R^{2}$ \\
\hline Panel A: original sample, & $1.6 .1997-9.30 .1997$ & & \\
\hline 3:30-3.35 p.m. & $-1 \times 10^{-5}$ & 0.126 & - & $11.3 \%$ \\
& $(-0.159)$ & $(4.147)$ & & $30.0 \%$ \\
3:35-3:40 p.m. & $-1 \times 10^{-4}$ & 0.586 & -0.179 & \\
& $(-1.050)$ & $(6.282)$ & $(-3.161)$ & $33.8 \%$ \\
3:40-3:45 p.m. & $-1 \times 10^{-4}$ & 0.669 & -0.115 & \\
& $(-1.714)$ & $(8.259)$ & $(-2.422)$ & $53.7 \%$ \\
3:45-3:50 p.m. & $-2 \times 10^{-4}$ & 0.914 & -0.112 & \\
& $(-1.990)$ & $(12.815)$ & $(-1.408)$ & $40.4 \%$ \\
3:50-3:55 p.m. & $-2 \times 10^{-4}$ & 0.817 & -0.003 & $44.9 \%$ \\
& $(-1.975)$ & $(8.348)$ & $(-0.283)$ & \\
3:55-4:00 p.m. & $-7 \times 10^{-7}$ & 1.031 & 0.039 & $58.1 \%$ \\
& $(-0.007)$ & $(5.779)$ & $(0.470)$ & \\
4:00-4:05 p.m. & $3 \times 10^{-5}$ & 0.968 & 0.069 & $49.3 \%$ \\
4:05-4:10 p.m. & $(0.343)$ & $(10.849)$ & $(0.568)$ & \\
& $-4 \times 10^{-4}$ & 0.963 & -0.158 & $52.4 \%$ \\
4:10-4:15 p.m. & $(-0.384)$ & $(8.342)$ & $(-1.490)$ & \\
& $2 \times 10^{-5}$ & 1.040 & 0.057 & $(0.555)$ \\
\end{tabular}




\begin{tabular}{|c|c|c|c|c|}
\hline Time interval & $\beta_{0}$ & $\beta_{1}$ & $\beta_{2}$ & Adjusted $R^{2}$ \\
\hline $4: 15-4: 20$ p.m. & $\begin{array}{l}1 \times 10^{-4} \\
(1.377)\end{array}$ & $\begin{array}{c}0.775 \\
(7.413)\end{array}$ & $\begin{array}{c}0.036 \\
(0.310)\end{array}$ & $29.1 \%$ \\
\hline $4: 20-4: 25$ p.m. & $\begin{array}{l}2 \times 10^{-4} \\
(2.176)\end{array}$ & $\begin{array}{c}0.897 \\
(12.269)\end{array}$ & $\begin{array}{l}-0.011 \\
(-0.119)\end{array}$ & $42.3 \%$ \\
\hline 4:25-4:30 p.m. & $\begin{array}{l}4 \times 10^{-4} \\
(4.149)\end{array}$ & $\begin{array}{c}0.813 \\
(3.899) \\
\end{array}$ & $\begin{array}{l}-0.115 \\
(-0.579) \\
\end{array}$ & $19.6 \%$ \\
\hline \multicolumn{5}{|c|}{ Panel B: holdout sample, 10.2.1997-6.26.1998 } \\
\hline 3:30-3.35 p.m. & $\begin{array}{l}1 \times 10^{-4} \\
(1.459)\end{array}$ & $\begin{array}{c}0.049 \\
(2.072)\end{array}$ & - & $2.4 \%$ \\
\hline 3:35-3:40 p.m. & $\begin{array}{c}-5 \times 10^{-5} \\
(-0.635)\end{array}$ & $\begin{array}{c}0.534 \\
(6.496)\end{array}$ & $\begin{array}{l}-0.202 \\
(-5.532)\end{array}$ & $39.1 \%$ \\
\hline $3: 40-3: 45$ p.m. & $\begin{array}{l}8 \times 10^{-6} \\
(0.104)\end{array}$ & $\begin{array}{c}0.574 \\
(7.713)\end{array}$ & $\begin{array}{l}-0.226 \\
(-3.794)\end{array}$ & $39.6 \%$ \\
\hline $3: 45-3: 50$ p.m. & $\begin{array}{c}-1 \times 10^{-4} \\
(-1.520)\end{array}$ & $\begin{array}{c}0.832 \\
(10.656)\end{array}$ & $\begin{array}{l}-0.053 \\
(-0.856)\end{array}$ & $54.8 \%$ \\
\hline 3:50-3:55 p.m. & $\begin{array}{c}-7 \times 10^{-5} \\
(-1.036)\end{array}$ & $\begin{array}{c}0.789 \\
(12.547)\end{array}$ & $\begin{array}{l}-0.144 \\
(-2.086)\end{array}$ & $51.1 \%$ \\
\hline 3:55-4:00 p.m. & $\begin{array}{c}-6 \times 10^{-5} \\
(-1.063)\end{array}$ & $\begin{array}{c}0.850 \\
(11.568)\end{array}$ & $\begin{array}{l}-0.085 \\
(-1.244)\end{array}$ & $54.0 \%$ \\
\hline 4:00-4:05 p.m. & $\begin{array}{c}-1 \times 10^{-4} \\
(-1.671)\end{array}$ & $\begin{array}{c}0.933 \\
(12.816)\end{array}$ & $\begin{array}{l}-0.090 \\
(-0.789)\end{array}$ & $62.2 \%$ \\
\hline 4:05-4:10 p.m. & $\begin{array}{c}9 \times 10^{-6} \\
(0.128)\end{array}$ & $\begin{array}{c}0.764 \\
(8.174)\end{array}$ & $\begin{array}{l}-0.154 \\
(-1.696)\end{array}$ & $39.5 \%$ \\
\hline 4:10-4:15 p.m. & $\begin{array}{l}3 \times 10^{-5} \\
(0.330)\end{array}$ & $\begin{array}{c}0.799 \\
(9.323)\end{array}$ & $\begin{array}{c}-0.115 \\
(-1.105)\end{array}$ & $40.8 \%$ \\
\hline $4: 15-4: 20$ p.m. & $\begin{array}{l}3 \times 10^{-4} \\
(0.307)\end{array}$ & $\begin{array}{c}0.869 \\
(12.906)\end{array}$ & $\begin{array}{l}-0.093 \\
(-0.892)\end{array}$ & $46.7 \%$ \\
\hline $4: 20-4: 25$ p.m. & $\begin{array}{l}5 \times 10^{-5} \\
(0.773)\end{array}$ & $\begin{array}{c}0.907 \\
(10.739)\end{array}$ & $\begin{array}{l}-0.057 \\
(-0.767)\end{array}$ & $47.1 \%$ \\
\hline 4:25-4:30 p.m. & $\begin{array}{c}3 \times 10^{-4} \\
(3.111)\end{array}$ & $\begin{array}{c}0.549 \\
(5.235)\end{array}$ & $\begin{array}{l}-0.248 \\
(-2.208)\end{array}$ & $15.6 \%$ \\
\hline
\end{tabular}




\subsubsection{Return Volatility Changes}

The results of estimating the regression Equation (4) for the SPI are reported in Table 4. We distinguish between days with and days without major macroeconomic announcements. The OLS regression residuals display first-order autocorrelation, which is why the numbers shown in parentheses are once again $t$-statistics based on standard errors corrected for heteroskedasticity and autocorrelation according to Newey and West.

Let us consider days with major macroeconomic news releases first. The associated findings are displayed in column (1) of the table. Throughout the paper, unless otherwise stated, highly significant denotes confidence better than 0.99 in a one-sided test against zero. The regression has fairly large explanatory power - the adjusted $R^{2}$ is $79 \%$. Moreover, the coefficients of time are statistically highly significant. Simple calculations reveal that they imply a U-shaped volatility pattern during the particular time of the day covered by the regression. Both observations apply to all subsequent regressions, which is why we will not repeat them.

The binary variable that defines the release of major macroeconomic news $\left(D_{\text {macro }}^{S P I}\right)$ has a positive and significant coefficient, consistent with the hypothesis that this information is relevant to companies traded on the SWX. The news in question has more than a temporary effect, since the coefficient of the variable $\left(D_{t o t}^{S P I}\right)$ is also positive and highly significant. Apparently, macroeconomic news releases induce an immediate rise in SWX volatility that lasts in part until the end of trading at 4:30 p.m. Specifically, note that with values of $0.059 \times 10^{-2}$ and $0.026 \times 10^{-2}$, respectively, the coefficients associated with the variables $D_{\text {macro }}^{S P I}$ and $D_{\text {tot }}^{S P I}$ imply a $230 \%$-spike $\left(=\left(0.059 \times 10^{-2}+0.026 \times 10^{-2}\right) /\left(0.037 \times 10^{-2}\right) \times 100\right)$ in volatility during the 9-minute interval of 2:29-2:38 immediately preceding and following the releases. ${ }^{20}$ As indicated by the $0.026 \times 10^{-2}$-coefficient associated with $D_{t o t}^{S P I}$, a sizable fraction of that increase lasts until the end of the trading day. In particular, and keeping in mind that return volatility would otherwise grow along its U-shaped pattern, the news disclosure causes a protracted increase in return volatility equal to $\left.70 \%\left(=0.026 \times 10^{-2}\right) /\left(0.037 \times 10^{-2}\right) \times 100\right)$ of what the volatility would otherwise be at 2:30 p.m. This volatility hike then declines during the day in relative terms; by the time the exchange closes at 4:30 p.m., the effect

20 Without a news release, the return volatility at 2:30 p.m. would be $0.037 \times 10^{-2}$. To see that, use the intercept estimate and the time coefficients in column (1), and note that 2:30 p.m. falls in the time interval 2:29-2:32 p.m. and therefore in the time interval $t=4+3 / 20=4.15$. Together, that implies a volatility of $0.064 \times 10^{-2}-0.016 \times 10^{-2} \times 4.15+0.228 \times 10^{-4} \times 4.15^{2}=0.037 \times 10^{-2}$. 


\section{Table 4: Intraday SPI-volatility Patterns: Regression Estimates (Original Sample)}

The table reports the results of a regression analysis of the determinants of intraday stock return volatility. The regression is estimated with ordinary least squares (OLS). Columns (1) and (2) report regression coefficients. Numbers in parentheses are $t$-statistics based on standard errors corrected for heteroskedasticity and autocorrelation according to Newey and West. Estimation period: 1.6.1997-9.30.1997.

\begin{tabular}{|c|c|c|c|}
\hline $\begin{array}{l}\text { Independent } \\
\text { variables }\end{array}$ & $\begin{array}{l}\text { Days with major } \\
\text { U.S. macroeconomic } \\
\text { announcements } \\
\text { (1) }\end{array}$ & $\begin{array}{l}\text { Days without major } \\
\text { U.S. macroeconomic } \\
\text { announcements } \\
\text { (2) }\end{array}$ & $\begin{array}{c}\text { Comparison test } \\
\text { of coefficients } \\
t \text {-values } \\
\text { (3) }\end{array}$ \\
\hline Constant & $\begin{array}{c}0.064 \times 10^{-2} \\
(23.057)\end{array}$ & $\begin{array}{c}0.064 \times 10^{-2} \\
(33.348)\end{array}$ & 0.000 \\
\hline$t$ & $\begin{array}{c}-0.016 \times 10^{-2} \\
(-4.716)\end{array}$ & $\begin{array}{c}-0.020 \times 10^{-2} \\
(-7.820)\end{array}$ & 10.440 \\
\hline$t^{2}$ & $\begin{array}{c}0.228 \times 10^{-4} \\
(2.748)\end{array}$ & $\begin{array}{c}0.335 \times 10^{-4} \\
(5.043)\end{array}$ & -11.170 \\
\hline$D_{\text {macro }}^{S P I}$ & $\begin{array}{c}0.059 \times 10^{-2} \\
\quad(7.471)\end{array}$ & $\begin{array}{c}0.912 \times 10^{-4} \\
(3.910)\end{array}$ & 67.180 \\
\hline$D_{t o t}^{S P I}$ & $\begin{array}{c}0.026 \times 10^{-2} \\
(4.623)\end{array}$ & $\begin{array}{c}0.482 \times 10^{-4} \\
(0.976)\end{array}$ & 31.380 \\
\hline$D_{W S o p e n}^{S P I}$ & $\begin{array}{c}-0.014 \times 10^{-2} \\
(-3.439)\end{array}$ & $\begin{array}{c}-0.013 \times 10^{-2} \\
(-4.212)\end{array}$ & -2.170 \\
\hline$D_{\text {overlap }}^{S P I}$ & $\begin{array}{c}0.968 \times 10^{-4} \\
(1.224)\end{array}$ & $\begin{array}{l}0.482 \times 10^{-4} \\
(0.829)\end{array}$ & 5.490 \\
\hline Adjusted $R^{2}$ & 0.786 & 0.781 & \\
\hline $\begin{array}{l}\text { Number of } \\
\text { observations }\end{array}$ & 123 & 123 & \\
\hline
\end{tabular}

Variable Definitions

$t \quad=$ number of 3-minute intervals expressed as a fraction of an hour. This time index starts with a value of 0 at 10:20-10:23 a.m., when we record the first intraday SPI return. The last 3-minute interval refers to the time between 4:26 p.m. and 4:29 p.m. Consequently, $\mathrm{t} \in(0,1 / 20,2 / 20, \ldots, 62 / 20)$;

$D_{\text {macro }}^{S P I}=$ a binary variable equal to 1 during the 9-minute interval of $2: 29$ p.m.-2:38 p.m., and equal to 0 otherwise;

$D_{t o t}^{S P I}=$ a binary variable equal to 1 during the 120 -minute interval of 2:29 p.m.-4:29 p.m., and equal to 0 otherwise;

$D_{W S \text { open }}^{S P I}=$ a binary variable equal to 1 during the 9-minute interval of 3:20 p.m.-3:29 p.m., and equal to 0 otherwise; and,

$D_{\text {overlap }}^{S P I}=$ a binary variable equal to 1 during the 60 -minute interval of 3:29 p.m.-4:29 p.m., and equal to 0 otherwise. 
adds $\left.51 \%\left(=0.026 \times 10^{-2}\right) /\left(0.051 \times 10^{-2}\right) \times 100\right)$ to what the volatility would otherwise be. ${ }^{21}$

The results also show that the opening of Wall Street is preceded by a significant volatility decline. The coefficient of the variable $D_{W S o p e n}^{S P I}$ is negative and highly significant. That is contrary to our predictions. We will investigate this phenomenon further when examining what happens to trading volume.

The coefficient of the last binary variable in the table, $D_{\text {overlap }}^{\text {SP }}$, is also inconsistent with our predictions: Joint trading with Wall Street does not raise SWX return volatility. The coefficient of $D_{\text {overlap }}^{S P I}$ is positive but clearly insignificant at customary levels of confidence.

Column (2) of the table replicates the regression for days without major U.S. macroeconomic announcements. Compared to the first column, there are four main observations to make. First, the coefficient of $D_{\text {macro }}^{S P I}$ maintains a positive and significant coefficient. This could mean that the market reacts also to macroeconomic announcements ignored in our classification because of their YAHOO Finance rating lower than B-. Still, the coefficient reported in column (1) for days with major news releases, namely $0.059 \times 10^{-2}$, is more than six times larger than the one we find here $\left(0.912 \times 10^{-4}\right)$. The difference, as reported in column (3) of the table, is statistically highly significant. Hence, higher rated disclosures have a substantially larger impact than other disclosures.

The second thing to note is that, whatever announcements the market reacts to during the days without major macroeconomic releases, their effect is temporary since it does not affect SWX volatility during the rest of the day - the coefficient of $D_{t o t}^{S P I}$ is insignificantly different from zero at customary levels of confidence. The third observation is that the anticipation of the Wall Street open lowers return volatility also on days without major U.S. macroeconomic releases, since the coefficient of $D_{W S o p e n}^{S P I}$ is still negative and significant. In fact, the coefficient is numerically almost identical across the two samples. The anticipation of the Wall Street open therefore reduces return volatility by the same amount regardless whether it is preceded by major news releases. Fourth, and finally, the results confirm what we saw in column (1), namely that joint trading in the U.S. and Switzerland does not affect SWX return volatility.

21 Without a news release, the return volatility at 4:30 p.m. would be $0.051 \times 10^{-2}$. To see that, use again the intercept estimate and the time coefficients in column (1), and note that the last interval for the SPI data is that of 4:26-4:29 p.m., which corresponds to a value $t=6+2 / 20=6.1$. That implies a volatility of $0.064 \times 10^{-2}-0.016 \times 10^{-2} \times 6.1+0.228 \times 10^{-4} \times 6.1^{2}=0.051 \times 10^{-2}$. 
The variables $D_{\text {macro }}^{I}$ and $D_{\text {tot }}^{I}$ are chosen to distinguish between the short- and the long-term volatility impact of macroeconomic disclosures. Since the two variables overlap, however, there could be a multicollinearity problem. We investigated this potential problem by computing a variance-inflation factor for each argument in the regression. As it turns out, there is no serious multicollinearity problem (not shown). That applies, in particular, to the two binary variables in question, for which the factor is below 7 (values between 10 and 100 would indicate moderate multicollinearity). The same conclusion holds for all our subsequent tables.

Table 5 replicates the analysis for the SMI. The purpose of this analysis is to examine whether the same results obtain if we focus on the subset of the more liquid stocks on the SWX. A look at the table shows that the results are qualitatively identical to those we observe for the SPI. The difference is that almost all coefficients are numerically (although not statistically) slightly larger. As in the case of the SPI, the release of major macroeconomic news provides both an immediate and a prolonged boost to return volatility. Moreover, the anticipation of the Wall Street open is preceded by a reduction in volatility, regardless whether we look at the sub-sample with major U.S. macroeconomic announcements or without. Finally, joint trading with Wall Street does not raise the volatility on the SWX.

It is well documented that volatility behavior is asymmetric, i.e., that it increases more strongly in reaction to the disclosure of bad news compared to what it does in reaction to good news (see De goeij and Marquering (2004) and the literature cited therein). We do not have consensus information to distinguish good and bad news directly, but we can sort the announcements by whether they provoke a positive or a negative change in the stock index of interest, and replicate the analysis by distinguishing the two situations. When we do so for the SMI in Table 5, we obtain results that confirm the extant evidence - bad news impacts volatility three times more than good news does (not shown). We obtain the same result when investigating the holdout sample. Overall, the results suggest that the release of macroeconomic news in the U.S. raises uncertainty on the SWX (particularly if it is bad). During the first minutes immediately after that disclosure, return volatility of the SPI goes up $230 \%$; thereafter, it declines, but it stays at a level 50\%-70\% higher than normal. The SMI goes through similar changes. The results also indicate that investors on the SWX appear to slow down their trading right before the Wall Street open. Once that happens, return volatility goes back to normal. These two effects are the same regardless whether they are preceded by U.S. macroeconomic news disclosure.

We also examine a slightly different specification of our regression equation where we add a binary variable that identifies the first minutes after the Wall Street 


\section{Table 5: Intraday SMI-volatility Patterns: Regression Estimates (Original Sample)}

The table reports the results of a regression analysis of the determinants of intraday stock return volatility. The regression is estimated with ordinary least squares (OLS). Columns (1) and (2) report regression coefficients. Numbers in parentheses are $t$-statistics based on standard errors corrected for heteroskedasticity and autocorrelation according to Newey and West. Estimation period: 1.6.1997-9.30.1997.

\begin{tabular}{|c|c|c|c|}
\hline $\begin{array}{l}\text { Independent } \\
\text { variables }\end{array}$ & $\begin{array}{l}\text { Days with major } \\
\text { U.S. macroeconomic } \\
\text { announcements } \\
\text { (1) }\end{array}$ & $\begin{array}{l}\text { Days without major } \\
\text { U.S. macroeconomic } \\
\text { announcements } \\
\text { (2) }\end{array}$ & $\begin{array}{c}\text { Comparison test } \\
\text { of coefficients } \\
t \text {-values } \\
\text { (3) }\end{array}$ \\
\hline Constant & $\begin{array}{c}0.001 \\
(25.239)\end{array}$ & $\begin{array}{c}0.001 \\
(23.989)\end{array}$ & 0.00 \\
\hline$t$ & $\begin{array}{c}-0.035 \times 10^{-2} \\
(-5.629)\end{array}$ & $\begin{array}{c}-0.040 \times 10^{-2} \\
(-7.919)\end{array}$ & 5.48 \\
\hline$t^{2}$ & $\begin{array}{l}0.490 \times 10^{-4} \\
(3.545)\end{array}$ & $\begin{array}{l}0.619 \times 10^{-4} \\
\quad(5.952)\end{array}$ & -6.54 \\
\hline$D_{\text {macro }}^{S M I}$ & $\begin{array}{c}0.093 \times 10^{-2} \\
(6.246)\end{array}$ & $\begin{array}{c}0.999 \times 10^{-4} \\
(2.312)\end{array}$ & 46.98 \\
\hline$D_{t o t}^{S M I}$ & $\begin{array}{c}0.034 \times 10^{-2} \\
(2.669)\end{array}$ & $\begin{array}{l}0.535 \times 10^{-4} \\
(0.741)\end{array}$ & 17.17 \\
\hline$D_{W S \text { Sopen }}^{S M I}$ & $\begin{array}{c}-0.023 \times 10^{-2} \\
(-2.188)\end{array}$ & $\begin{array}{c}-0.018 \times 10^{-2} \\
(-4.293)\end{array}$ & -3.88 \\
\hline$D_{\text {overhap }}^{\text {SMI }}$ & $\begin{array}{l}0.016 \times 10^{-2} \\
(0.971)\end{array}$ & $\begin{array}{l}0.825 \times 10^{-4} \\
\quad(1.043)\end{array}$ & 3.72 \\
\hline Adjusted $R^{2}$ & 0.801 & 0.828 & \\
\hline $\begin{array}{l}\text { Number of } \\
\text { observations }\end{array}$ & 77 & 77 & \\
\hline
\end{tabular}

Variable Definitions

$t=$ number of 5-minute intervals expressed as a fraction of an hour. This time index starts with a value of 0 at 10:05-10:10 a.m., when we record the first intraday SMI return. The last 5-minute interval refers to the time between 4:25 p.m. and 4:30 p.m. Consequently, $t \in(0,1 / 12,2 / 12, \ldots, 64 / 12)$;

$D_{\text {macro }}^{\text {SMI }}=$ a binary variable equal to 1 during the 10 -minute interval of 2:30 p.m.-2:40 p.m., and equal to 0 otherwise;

$D_{t o t}^{S M I}=$ a binary variable equal to 1 during the 120 -minute interval of 2:30 p.m.-4:30 p.m., and equal to 0 otherwise;

$D_{W S \text { Sopen }}^{S M I}=$ a binary variable equal to 1 during the 10 -minute interval of 3:20 p.m.-3:30 p.m., and equal to 0 otherwise; and,

$D_{\text {overlap }}^{S M I}=$ a binary variable equal to 1 during the 60 -minute interval of 3:30 p.m.-4:30 p.m., and equal to 0 otherwise. 
open (not shown). The variable equals 1 during the 12-minute interval of 3:29 p.m. $-3: 41$ p.m., and equals 0 otherwise. We find no evidence of a spike in volatility at that time (the remaining results are essentially unchanged). This finding is inconsistent with the theoretical argument and the evidence reported in KING and WADHWANI (1990). It could be that the Wall Street open conveys less information in the years covered here (1997-1998) than it did at the time KING and WADHWANI performed their investigation, namely the period July 1987 to February 1988. Market participants can use various computerized order matching systems (so-called electronic communications networks, ECN) to trade before and after the trading hours of the major U.S. stock exchanges and NASDAQ, something that was not possible in 1987. Consequently, the formal opening of Wall Street might not reveal much that SWX traders do not already know. The problem with this interpretation is that, if indeed only little information is disclosed when Wall Street opens, it is not clear why return volatility dips right before that event.

In the following section, we investigate trading volume to see whether we can confirm our observations. In particular, we are interested in the changes in trading volume following major macroeconomic news releases and right before the Wall Street open.

\subsubsection{Trading Volume Changes}

Table 6 shows the results of estimating the regression Equation (4) with trading volume as the dependent variable. Since the residuals of the regression are generally autocorrelated, we once again correct the standard errors for heteroskedasticity and autocorrelation according to Newey and West. Overall, the findings are very similar to those reported for return volatility. The only exception is that trading volume seems to decline during the time of joint trading. But let us discuss these findings in more detail.

Consider the case of days with major U.S. macroeconomic news first [column (1) of the table]. Based on the coefficients associated with $D_{\text {macro }}$ and $D_{\text {tot }}$, the disclosure of that information boosts the number of shares traded by about 34,766 $(=24,751+10,015)$ units compared to the $13,072.30$ one would in principle observe at 2:30 p.m.; ${ }^{22}$ this is a substantial $266 \%(=34,766 / 13,072)$ jump. Moreover, following that announcement, trading volume remains unusually high, namely by about 10,015 units according to the coefficient of $D_{t o t}$. Since

22 To obtain the latter figure, we use intercept estimate as well as time coefficient estimates. Keeping in mind that 2:30 p.m. corresponds to a value $t=4+5 / 12=4.417$ for volume figures, we compute $38,891.61-17,748.24 \times 4.417+2,694.77 \times 4.417^{2}=13,072.30$. 
Table 6: Intraday Trading Volume Patterns: Regression Estimates (Original Sample)

The table reports the results of a regression analysis of the determinants of intraday trading volume, defined as number of shares traded in eight blue chips on the SWX. The regression is estimated with ordinary least squares (OLS). Columns (1) and (2) report regression coefficients. Numbers in parentheses are $t$-statistics based on standard errors corrected for heteroskedasticity and autocorrelation according to Newey and West. Estimation period: 1.6.1997-9.30.1997.

\begin{tabular}{lccc}
\hline $\begin{array}{l}\text { Independent } \\
\text { variables }\end{array}$ & $\begin{array}{c}\text { Days with major } \\
\text { U.S. macroeconomic } \\
\text { announcements } \\
(1)\end{array}$ & $\begin{array}{c}\text { Days without major } \\
\text { U.S. macroeconomic } \\
\text { announcements } \\
(2)\end{array}$ & $\begin{array}{c}\text { Comparison test } \\
\text { of coefficients } \\
t \text {-values } \\
(3)\end{array}$ \\
\hline Constant & $\begin{array}{c}38,891.61 \\
(30.829)\end{array}$ & $\begin{array}{c}41,050.22 \\
(27.278)\end{array}$ & -9.58 \\
\hline$t$ & $-17,748.24$ & $-19,205.28$ & \\
$(-13.486)$ & $(-12.853)$ & 6.38 \\
\hline$t^{2}$ & $2,694.77$ & $2,932.64$ & -4.54 \\
& $(8.906)$ & $(8.580)$ & 26.40 \\
\hline$D_{\text {macro }}$ & $24,750.52$ & $3,391.46$ & 16.11 \\
\hline$D_{\text {tot }}$ & $(3.646)$ & $(1.774)$ & \\
\hline$D_{\text {WSopen }}$ & $10,014.97$ & $2,169.46$ & -18.88 \\
\hline$D_{\text {overlap }}$ & $(3.678)$ & $(0.666)$ & -7.70 \\
\hline Adjusted $R^{2}$ & $-12,241.32$ & $-6,049.09$ & \\
\hline Number of & $(-8.467)$ & $(-2.453)$ & \\
observations & $-6,612.78$ & $-3,186.66$ & $(-1.084)$ \\
\hline
\end{tabular}

Variable Definitions

$t=$ number of 5 -minute intervals expressed as a fraction of an hour. This time index starts with a value of 0 at 10:05-10:10 a.m., when we record the first trading volume figure. The last 5-minute interval refers to the time between 4:20 p.m. and 4:25 p.m. Consequently, $t \in(0,1 / 12,2 / 12, \ldots, 63 / 12)$;

$D_{\text {macro }}=$ a binary variable equal to 1 during the 10 -minute interval of 2:30 p.m.-2:40 p.m., and equal to 0 otherwise;

$D_{t o t}=$ a binary variable equal to 1 during the 115 -minute interval of 2:30 p.m.-4:25 p.m., and equal to 0 otherwise;

$D_{\text {WSopen }}=$ a binary variable equal to 1 during the 10 -minute interval of 3:20 p.m.-3:30 p.m., and equal to 0 otherwise; and,

$D_{\text {overlap }}=$ a binary variable equal to 1 during the 55 -minute interval of 3:30 p.m.- $4: 25$ p.m., and equal to 0 otherwise. 
trading volume would normally follow a U-shaped pattern during the day, this increase changes in relative terms as the day goes by. Specifically, right after the announcement, the rise is $77 \%(=10.014 .97 / 13,072.30)$ whereas by the end of the day it is $28 \%(=10,014.97 / 35,966.09) .{ }^{23}$ Both figures seem to be economically significant.

Consistent with what happens to return volatility, trading volume plunges later in the day in anticipation of the Wall Street open - the decline equals 12,241 shares or $41 \%(=12,241.32 / 30,002.92){ }^{24}$ This seems to indicate that traders do not reshuffle their positions in anticipation of the upcoming open, since that would increase return volatility and trading volume. Traders simply seem to wait and see. But once Wall Street has opened, trading volume does not appear to go back up to normal levels. As indicated by the negative and significant coefficient of $D_{\text {overlap }}$, trading overlap is associated with lower trading volume.

The analysis of the days without major macroeconomic news in column (2) of the table generally confirms the conclusions reached in the analysis of return volatility, namely that:

a. There is only a small volume hike, at 2:30 p.m., the time when major U.S. macroeconomic news is usually released. The coefficient of the variable $D_{\text {macro }}$ is not significantly different from zero with confidence 0.95 and is seven times smaller than that observed in column (1);

b. Trading volume remains unchanged from 2:30 until the end of the trading day (the coefficient of $D_{t o t}$ is insignificantly different from zero);

c. Trading volume falls right before the Wall Street open. The coefficient of $D_{\text {WSopen }}$ is negative and significant. It is, however, half the size of the coefficient observed in column (1). The anticipation of the Wall Street open therefore has a more pronounced effect on trading volume when it follows a macroeconomic disclosure at 2:30. This is in contrast with what we observe in Tables 4 and 5, where return volatility falls by the same amount regardless whether the open is preceded by a major macroeconomic news release; and,

d. There is no increase in volume on the SWX during the time both Wall Street and the SWX are open.

23 To obtain the theoretical number of shares traded at the end of the day in the absence of an announcement, we have to keep in mind that 4:30 p.m. corresponds to $t=6+5 / 12=6.417$. This yields a trading volume value of $38,891.61-17,748.24 \times 6.417+2,694.77 \times 6.417^{2}=35,966.09$.

24 To obtain the theoretical number of shares traded otherwise, we have to keep in mind that 3:20 p.m. corresponds to $t=5+3 / 12=5.250$. This yields a trading volume value of $38,891.61-17,748.24 \times 5.250+2,694.77 \times 5.250^{2}+10,014.97=30,002.92$. 


\subsection{Holdout Sample}

\subsubsection{Intraday Correlation between Wall Street and the Swiss Stock Exchange}

The regularities observed in the original sample can be confirmed in the holdout sample (Panel B of Table 3). There is a strong contemporaneous relation between the SMI and the S\&P 500, except during the first 15 minutes of common trading (especially the first five). However, the adjusted $R^{2}$ of the regression is again mostly below $50 \%$. More importantly, we still find traces of an overreaction of the SMI to the S\&P 500. The lagged relation between the SMI and the S\&P 500 is always negative from the opening of Wall Street at 3:30 p.m. until the closing of the SWX at 4:30 p.m., particularly during the first 15 minutes of joint trading when the coefficient in question has $t$-values of -5.5 and -3.8 , respectively. As in the case of the original sample, the lagged coefficient is substantially weaker than the contemporaneous coefficient and could hardly justify a trading strategy. Still, this finding seems to confirm the claim that the SWX reacts to what happens on Wall Street.

\subsubsection{Return Volatility Changes}

To confirm our results concerning the intraday evolution of return volatility, we repeat the analysis of Tables 4 and 5 with the holdout sample. We report here only the findings of the investigation conducted for the SMI. The examination of the SPI yields qualitatively the same conclusions. The relevant numbers are shown in Table 7 for both days with and without major U.S. macroeconomic disclosures.

In general, the results confirm what we find for the original sample. To document this, let us consider the days with major macroeconomic announcements first. Table 7 shows the associated figures in column (1). As in the original sample, the disclosure of macroeconomic news has both a sizable temporary and a prolonged influence on stock return volatility, as measured by the positive and highly significant coefficients of the variables $D_{\text {macro }}^{S M I}$ and $D_{t o t}^{S M I}$. Note, however, that the temporary effect is substantially smaller than the effect observed in the original sample. We also observe that the opening of Wall Street is still preceded by a significant and sizable decline in volatility, as indicated by the negative coefficient of the variable $D_{W S \text { Sopen }}^{S M I}$. Furthermore, trading overlap still does not impact volatility - the coefficient of the variable $D_{\text {overlap }}^{S M I}$ is not significantly different from zero.

Consider next the days without major macroeconomic announcements. According to the estimates reported in column (2) of the table, the spike in volatility at the time when macroeconomic announcements are usually made is 


\section{Table 7: Intraday SMI-volatility Patterns: Regression Estimates (Holdout Sample)}

The table reports the results of a regression analysis of the determinants of intraday stock return volatility. The regression is estimated with ordinary least squares (OLS). Columns (1) and (2) report regression coefficients. Numbers in parentheses are $t$-statistics based on standard errors corrected for heteroskedasticity and autocorrelation according to Newey and West. Estimation period: 10.2.1997-6.26.1998.

\begin{tabular}{|c|c|c|c|}
\hline $\begin{array}{l}\text { Independent } \\
\text { variables }\end{array}$ & $\begin{array}{l}\text { Days with major } \\
\text { U.S. macroeconomic } \\
\text { announcements } \\
\text { (1) }\end{array}$ & $\begin{array}{l}\text { Days without major } \\
\text { U.S. macroeconomic } \\
\text { announcements } \\
\text { (2) }\end{array}$ & $\begin{array}{c}\text { Comparison test } \\
\text { of coefficients } \\
t \text {-values } \\
\text { (3) }\end{array}$ \\
\hline Constant & $\begin{array}{c}0.001 \\
(16.947)\end{array}$ & $\begin{array}{c}0.001 \\
(27.353)\end{array}$ & 0.00 \\
\hline$t$ & $\begin{array}{c}-0.039 \times 10^{-2} \\
(-6.115)\end{array}$ & $\begin{array}{c}-0.039 \times 10^{-2} \\
(-8.562)\end{array}$ & 0.00 \\
\hline$t^{2}$ & $\begin{array}{c}0.565 \times 10^{-4} \\
(4.822)\end{array}$ & $\begin{array}{l}0.683 \times 10^{-4} \\
\quad(6.971)\end{array}$ & -6.78 \\
\hline$D_{\text {macro }}^{S M I}$ & $\begin{array}{l}0.059 \times 10^{-2} \\
\quad(4.571)\end{array}$ & $\begin{array}{c}0.014 \times 10^{-2} \\
(2.360)\end{array}$ & 27.80 \\
\hline$D_{t o t}^{S M I}$ & $\begin{array}{l}0.027 \times 10^{-2} \\
(3.139)\end{array}$ & $\begin{array}{c}-0.015 \times 10^{-2} \\
(-1.962)\end{array}$ & 32.03 \\
\hline$D_{\text {WSopen }}^{S M I}$ & $\begin{array}{c}-0.029 \times 10^{-2} \\
(-4.715)\end{array}$ & $\begin{array}{c}-0.028 \times 10^{-2} \\
(-8.381)\end{array}$ & -1.25 \\
\hline$D_{\text {overlap }}^{S M I}$ & $\begin{array}{c}-0.369 \times 10^{-4} \\
(-0.387)\end{array}$ & $\begin{array}{c}0.071 \times 10^{-4} \\
(0.122)\end{array}$ & -3.46 \\
\hline Adjusted $R^{2}$ & 0.751 & 0.739 & \\
\hline $\begin{array}{l}\text { Number of } \\
\text { observations }\end{array}$ & 77 & 77 & \\
\hline
\end{tabular}

Variable Definitions

$t=$ number of 5-minute intervals expressed as a fraction of an hour. This time index starts with a value of 0 at 10:05-10:10 a.m., when we record the first intraday SMI return. The last 5-minute interval refers to the time between 4:25 p.m. and 4:30 p.m. Consequently, $t \in(0,1 / 12,2 / 12, \ldots, 64 / 12)$;

$D_{\text {macro }}^{S M I}=$ a binary variable equal to 1 during the 10 -minute interval of 2:30 p.m.-2:40 p.m., and equal to 0 otherwise;

$D_{t o t}^{S M I} \quad=$ a binary variable equal to 1 during the 120 -minute interval of 2:30 p.m.-4:30 p.m., and equal to 0 otherwise;

$D_{W S o p e n}^{S M I}=$ a binary variable equal to 1 during the 10 -minute interval of 3:20 p.m.-3:30 p.m., and equal to 0 otherwise; and,

$D_{\text {overlap }}^{S M I}=$ a binary variable equal to 1 during the 60 -minute interval of $3: 30$ p.m. $-4: 30$ p.m., and equal to 0 otherwise. 
still statistically significant. The coefficient of $D_{\text {macro }}^{S M I}$ is positive as in the original sample in Table $3\left(0.014 \times 10^{-2}\right.$ here compared to $0.999 \times 10^{-4}$ there). As we pointed out, this probably shows that other U.S. macroeconomic announcements are forthcoming at 2:30 p.m., even though with lower YAHOO Finance rating than $\mathrm{B}-$. As in the original sample, however, the coefficient of $D_{\text {macro }}^{S M I}$ during days with major macroeconomic announcements is much larger (more than four times larger) than that observed during days without such announcements. The numbers reported in column (3) indicate that the difference is statistically highly significant. Similarly, there is no evidence of a prolonged volatility increase following the time of these announcements. If anything, the negative coefficient of $D_{t o t}^{S M I}$ suggests a volatility decline. Moreover, the data buttress the evidence of a volatility dip right before Wall Street's opening - the coefficient of $D_{W S o p e n}^{S M I}$ is negative, highly significant, and almost identical to that reported in column (1) of the table. Finally, there is once again no evidence of a volatility increase during the time both markets are open - the coefficient of $D_{\text {overlap }}^{S M I}$ is not significantly different from zero.

\subsubsection{Changes in Trading Volume}

The volume data from the holdout period yield implications that are also equally in line with what we obtain for the original sample. The results are in Table 8. In column (1) of the table, we find that major U.S. macroeconomic announcements induce a sharp increase in the number of shares traded at the time they are released - the coefficient of the variable $D_{\text {macro }}$ is significantly different from zero. Note, however, that the increase is substantially smaller than that observed in the original sample. Following the news release, trading volume goes back somewhat but stabilizes until the end of trading at a level that is substantially higher than what we would observe otherwise - the coefficient of $D_{t o t}$ is positive and significant, although almost half the size of the coefficient of $D_{\text {macro }}$. In addition to that, the data support the claim that the forthcoming opening of Wall Street induces investors to slow down their trading significantly - the coefficient of $D_{W S o p e n}$ is negative and significant. Finally, the evidence again rejects the notion that joint trading on Wall Street and the SWX increases trading volume on the SWX.

Column (2) of the table shows the results for the sample without major macroeconomic disclosures. They are fully consistent with those reported in Table 6. The only exception is the increase in trading volume at 2:30 p.m., the time major U.S. macroeconomic disclosures are usually forthcoming. That increase is statistically significant now, whereas it is only marginally so in the original sample. The magnitude of the increase is, however, similar across samples. Moreover, it is less 


\section{Table 8: Intraday Trading Volume Patterns: Regression Estimates (Holdout Sample)}

The table reports the results of a regression analysis of the determinants of intraday trading volume, defined as number of shares traded. The regression is estimated with ordinary least squares (OLS). Columns (1) and (2) report regression coefficients. Numbers in parentheses are $t$-statistics based on standard errors corrected for heteroskedasticity and autocorrelation according to Newey and West. Estimation period: 10.2.1997-6.26.1998.

\begin{tabular}{lccc}
\hline $\begin{array}{l}\text { Independent } \\
\text { variables }\end{array}$ & $\begin{array}{c}\text { Days with major } \\
\text { U.S. macroeconomic } \\
\text { announcements } \\
(1)\end{array}$ & $\begin{array}{c}\text { Days without major } \\
\text { U.S. macroeconomic } \\
\text { announcements } \\
(2)\end{array}$ & $\begin{array}{c}\text { Comparison test } \\
\text { of coefficients } \\
t \text {-values } \\
(3)\end{array}$ \\
\hline Constant & $\begin{array}{c}34,494.44 \\
(24.737)\end{array}$ & $\begin{array}{c}33,980.27 \\
(45.826)\end{array}$ & 2.84 \\
\hline$t$ & $-15,029.20$ & $-15,069.38$ & 0.22 \\
$(-11.542)$ & $(-16.794)$ & -2.65 \\
$t^{2}$ & $2,228.71$ & $2,330.21$ & 19.88 \\
& $(8.914)$ & $(10.550)$ & 10.29 \\
\hline$D_{\text {macro }}$ & $7,023.06$ & $3,041.54$ & -14.65 \\
\hline$D_{\text {tot }}$ & $(5.052)$ & $(2.880)$ & 0.20 \\
\hline$D_{\text {WSopen }}$ & $4,231.30$ & 882.574 & \\
\hline$D_{\text {overlap }}$ & $(2.207)$ & $(0.422)$ & \\
\hline Adjusted $R^{2}$ & $-7,362.89$ & $-4,229.57$ & $(-3.324)$ \\
\hline Number of & $(-5.402)$ & -378.869 & $(-0.201)$ \\
observations & -309.84 & 0.931 & \\
\hline
\end{tabular}

Variable Definitions

$t \quad=$ number of 5-minute intervals expressed as a fraction of an hour. This time index starts with a value of 0 at 10:05-10:10 a.m., when we record the first trading volume figure. The last 5-minute interval refers to the time between 4:20 p.m. and 4:25 p.m. Consequently, $t \in(0,1 / 12,2 / 12, \ldots, 63 / 12)$;

$D_{\text {macro }}=$ a binary variable equal to 1 during the 10 -minute interval of 2:30 p.m.-2:40 p.m., and equal to 0 otherwise;

$D_{\text {tot }} \quad=$ a binary variable equal to 1 during the 115 -minute interval of 2:30 p.m.-4:25 p.m., and equal to 0 otherwise;

$D_{\text {WSopen }}=$ a binary variable equal to 1 during the 10-minute interval of 3:20 p.m.-3:30 p.m., and equal to 0 otherwise; and,

$D_{\text {overlap }}=$ a binary variable equal to 1 during the 55-minute interval of 3:30 p.m.-4:25 p.m., and equal to 0 otherwise. 
than half the size as that observed on days with major news releases. Hence, the possible news releases in question would seem to be comparatively less important. Consistent with that, the increase in trading volume is only temporary, since the coefficient of $D_{t o t}$ is essentially zero (on days with major macroeconomic disclosures, trading volume remains abnormally high until the close of trading). We also find that trading volume declines right before Wall Street opens, but later remains unaffected when both the U.S. and the Swiss exchanges are open.

\subsection{Robustness Test}

In the preceding tests, we assumed that the uncertainty generated by macroeconomic announcements persists until the end of trading on the SWX. It is possible, however, that this uncertainty does not last that long. We therefore replicate the analysis and replace the binary variable $D_{t o t}^{S M I}$ with the binary variable $D_{\text {proopen }}^{S M I}$, which identifies the time between 2:40 p.m. and 3:20 p.m., i.e., the period immediately following the macroeconomic release and preceding the Wall Street opening. The time after the opening is still identified with the variable $D_{\text {overlap }}^{S M I}$. An implied benefit from this specification is that we can take another look at whether the period of joint trading affects return volatility. In assuming, as we did so far, that the uncertainty induced by macroeconomic news releases lasts until the SWX close, we may end up erroneously attributing a possible increase in return volatility (and trading volume) during the period of joint trading to the macroeconomic announcements.

The results are summarized in Table 9 for both return volatility and trading volume. For simplicity, we show only the estimates that refer to SMI return volatility and trading volume. The results concerning the SPI return volatility are qualitatively identical to those pertaining to the SMI return volatility. To avoid unnecessary clutter, we report only the coefficient estimates associated with the binary variables in the regression.

As one can see from the table, even under the new specification, there is little evidence that joint trading boosts return volatility. The only instance in which the coefficient of $D_{\text {overlap }}^{S M I}$ is positive and significant is on days with major macroeconomic news releases. During days without such releases, the coefficient is zero. And it is similarly zero in all the regressions involving trading volume. In contrast, the coefficient associated with the binary variable $D_{\text {proepen }}^{S M I}$, which marks the period immediately following the macroeconomic release and preceding the Wall Street opening, is positive and significant, but only following a major macroeconomic announcement. Consequently, the significant coefficient of $D_{t o t}^{S M I}$ we find in the preceding tables cannot possibly be induced by joint trading. Rather, 


\section{Table 9: Intraday SMI Volatility and Trading Volume Patterns: Regression Estimates} (Original and Holdout Samples)

The table reports the results of a regression analysis of the determinants of intraday stock return volatility and of intraday trading volume, respectively. Trading volume is defined as number of shares traded. The regression is estimated with ordinary least squares (OLS). Each column reports regression coefficients. Numbers in parentheses are $t$-statistics based on standard errors corrected for heteroskedasticity and autocorrelation according to Newey and West. Estimation period: 1.6.1997-6.26.1998.

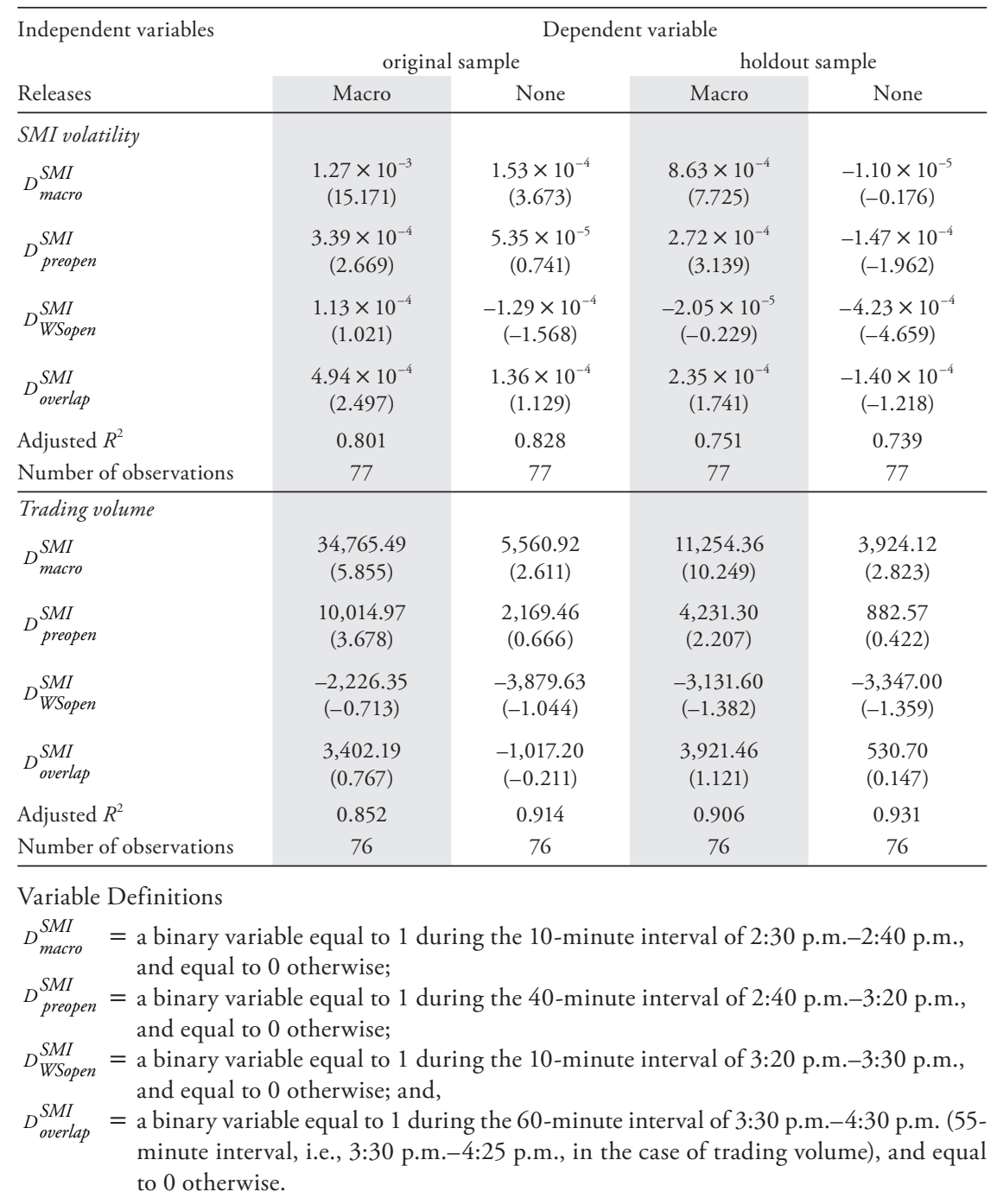


it would seem to be related to the news release itself. Modeling, as we did above, the impact of major news releases as lasting until the end of trading would therefore seem to be appropriate.

As for the remaining coefficients of interest, we obtain the following results. The coefficient of the binary variable that defines the time of macroeconomic news releases, $D_{\text {macro }}^{S M I}$, is still positive and significant, and substantially larger on days with news release than on days without. And the coefficient of $D_{W S \text { Sopen }}^{S M I}$ is almost always zero.

Taken together, these results indicate that the specification tested previously, namely that macroeconomic news releases can affect return volatility until the end of trading, seems to be the more appropriate one. It provides the correct interpretation of the impact of major macroeconomic news releases (the impact lasts until the end of the trading day in the case of both return volatility and trading volume) and it does not hide the impact of the Wall Street open.

\section{Conclusions}

This paper asks whether and in what sense, as argued frequently in the press and by financial analysts, the Swiss stock market depends on Wall Street. We ask whether macroeconomic news that is relevant to Wall Street also affects the SWX. Moreover, we investigate the correlation between the two markets from the time Wall Street opens to the time the SWX closes looking for evidence of a lagged relation. And we study how the opening of Wall Street affects the return volatility and the trading volume on the SWX. We use an original sample for a preliminary test of regularities, and a holdout sample to confirm our findings.

The results are fairly consistent across samples and variables. The relation between Wall Street and the SWX is indeed high, confirming a close tie between the two markets. Most of this relation is contemporaneous. The SWX, however, seems to overreact to what happens on Wall Street and to correct that reaction a few minutes later, especially during the first 15 minutes after Wall Street opens. This overreaction does not appear to be strong enough to imply profitable trading strategies. Still, its occurrence supports the contention that SWX traders wait to see what happens on Wall Street.

We also find that major U.S. news releases and the opening of Wall Street affect the Swiss stock market. The release of major macroeconomic news causes return volatility and trading volume to go up significantly. This increase is not only momentary but it persists until the end of the trading day. In contrast, there is no evidence of a spike in return volatility or in trading volume when Wall 
Street opens. If anything, it seems that investors slow down their trades before that event - return volatility declines and trading volume falls. Still, this is consistent with the claim that what happens on Wall Street affects the SWX. In the case of trading volume, this effect seems to be more pronounced when it is preceded by major U.S. macroeconomic news releases. Finally, there is no increase in return volatility or trading volume on the SWX when both markets are open, regardless whether there has been a major macroeconomic disclosure or not. The reduction in trading volume right before the Wall Street open is consistent with the arguments concerning trading before the scheduled release of information advanced by CHAE (2005). Our results show, however, that other scheduled information releases, namely the disclosure of macroeconomic news, is not preceded by a similar dip in trading. This differential pattern in trading volume is not shown in a separate table, but can be inferred from Figure 2.

The findings confirm the allegation that the Swiss stock market is tied to the U.S. market and that it depends in part on it. The SWX reacts to some of the same news that Wall Street reacts to. Moreover, traders appear to wait with some anticipation to see how Wall Street opens and they seem to overreact to trading on Wall Street. The relation between the two markets, however, is fairly noisy and there are other factors besides what happens in the U.S. that are equally relevant in determining the intraday returns on the SWX.

\section{References}

Admati, Anat R. and Paul Pfleiderer (1988), "A theory of Intraday Patterns: Volume and Price Variability", Review of Financial Studies, 1, pp.3-40.

Becker, Kent G., Joseph E. Finnerty, and Joseph Friedman (1995), "Economic News and Equity Market Linkages between the U.S. and U.K.", Journal of Banking and Finance, 19, pp. 1191-1210.

Chae, Joon (2005), "Trading Volume, Information Asymmetry, and Timing Information", Journal of Finance, 60, pp.413-442.

Chan, Kalok, K. C. Chan, and G. Andrew Karolyi (1991), "Intraday Volatility in the Stock Index and Stock Index Futures Markets", Review of Financial Studies, 4, pp. 657-684.

Connolly, Robert A. and F. Albert Wang (2003), "International Equity Market Comovements: Economic Fundamentals or Contagion?", Pacific-Basin Finance Journal, 11, pp. 23-43. 
De goeij, Peter and Wessel Marquering (2004), "Do Macroeconomic Announcements Cause Asymmetric Volatility?”, EFMA 2004 Basel Meetings Paper.

Ederington, Louis H. and Jae Ha Lee (1993), "How Markets Process Information: News Releases and Volatility”, Journal of Finance, 48, pp. 1161-1191.

Ederington, Louis H. and Jae Ha Lee (1996), "The Impact of Macroeconomic News on Financial Markets", Journal of Applied Corporate Finance, 9, pp. 41-49.

Eun, Cheol S. and Sangdal Shim (1989), "International Transmissions of Stock Market Movements", Journal of Financial and Quantitative Analysis, 24, pp. 241-256.

Fornari, Fabio (2004), "Macroeconomic Announcements and Implied Volatilities in Swaption Markets", BIS Quarterly Review, September, pp. 79-86.

French, Kenneth R. and Richard Roll (1986), "Stock Return Variances: The Arrival of Information and the Reaction of Traders", Journal of Financial Economics, 17, pp.5-26.

Gallant, A. Ronald, Peter E. Rossi, and George Tauchen (1992), "Stock Prices and Volume”, The Review of Financial Studies, 5, pp. 199-242.

Hamao, Yasushi, Ronald W. Masulis, and Victor NG (1990), "Correlations in Price Changes and Volatility across International Stock Markets”, Review of Financial Studies, 3, pp. 281-307.

Harris, Lawrence (1986), “A Transaction Data Study of Weekly and Intraday Patterns in Stock Returns", Journal of Financial Economics, 16, pp. 99-118.

Hiemstra, Craig and Jonathan D. Jones (1993), "Testing for Linear and Nonlinear Granger Causality in the Stock Price-volume Relationship”, Journal of Finance, 49, pp. 1639-1665.

Jain, Prem C. and Gun-Ho Joh (1988), "The Dependence between Hourly Prices and Trading Volume", Journal of Financial and Quantitative Analysis, 23, pp. 269-283.

Jones, Charles M., Owen Lamont, and Robin L. Lumsdaine (1998), "Macroeconomic News and Bond Market Volatility", Journal of Financial Economics, 47, pp. 315-337.

Kalay, Avner and Uri Loewenstein (1985), "Predictable Events and Excess Returns: The case of Dividend Announcements", Journal of Financial Economics, 14, pp. 423-449.

Karolyi, G. Andrew and René M. Stulz (1996), "Why do Markets Move Together? An Investigation of U.S.-Japan Stock Return Comovements", Journal of Finance, 51, pp.951-986. 
King, Mervyn A. and Sushil Wadhwani (1990), "Transmission of Volatility between Stock Markets", Review of Financial Studies, 3, pp. 5-33.

Li, Li and Robert F. Engle (1998), "Macroeconomic Announcements and Volatility of Treasury Futures", Discussion Paper 98-27, Dept. of Economics, University of California, San Diego.

Lin, Wen-Ling, Robert F. Engle, and Takatoshi Ito (1994), "Do Bulls and Bears Move across Borders? International Transmission of Stock Returns and Volatility", Review of Financial Studies, 7, pp. 507-538.

Lockwood, Larry J. and Scott C. Linn (1990), "An Examination of Stock Market Return Volatility during Overnight and Intraday Periods, 1964-1989", Journal of Finance, 45, pp. 591-601.

McQueen, Grant and V. Vance Roley (1993), "Stock Prices, News, and Business Conditions", Review of Financial Studies, 6, pp. 683-707.

Oertmann, Peter (1995), „Bestimmt die Wall Street das weltweite Börsengeschehen?", Finanzmarkt und Portfolio Management, 9, pp.433-445.

Patell, James M. and Mark A. Wolfson (1979), "Anticipated Information Releases Reflected in Call Option Prices", Journal of Accounting and Economics, 1, pp. 117-140.

Poitras, Marc (2004), "The Impact of Macroeconomic Announcements on Stock Prices: In Search of State Dependence", Southern Economic Journal, 70, pp. 549-565.

Ranaldo, Angelo (2004), "Order Aggressiveness in Limit Order Book Markets", Journal of Financial Markets, 7, pp. 53-74.

Stoll, Hans R. and Robert E. Whaley (1990), "Stock Market Structure and Volatility”, Review of Financial Studies, 3, pp. 37-71.

Susmel, Raul and Robert F. Engle (1994), "Hourly Volatility Spillovers between International Equity Markets", Journal of International Money and Finance, 13, pp. 3-25.

Wood, Robert A., Thomas H. McInish, and J. Keith Ord (1985), "An Investigation of Transactions Data for NYSE Stocks”, Journal of Finance, 40, pp. 723-739. 


\section{SUMMARY}

We want to know whether and in what sense traders on the Swiss Stock Exchange (SWX) are influenced by what happens on Wall Street. According to the results, the SWX reacts strongly when U.S. macroeconomic news relevant to Wall Street is disclosed. Moreover, SWX traders seem to wait with anticipation for the Wall Street opening. And they appear to overreact to what happens on Wall Street, although this overreaction is too weak to imply a profitable trading strategy.

\section{ZUSAMMENFASSUNG}

Mit dieser Arbeit gehen wir der Frage nach, ob sich Händler an der Schweizer Börse (SWX) durch Ereignisse an der Wall Street beeinflussen lassen. Die Ergebnisse zeigen, dass die SWX stark auf die Veröffentlichung U.S.-makroökonomischer Daten reagiert, welche auch für die Wall Street von Bedeutung sind. Darüber hinaus scheinen Händler an der SWX den Handelsbeginn an der Wall Street um 15:30 MEZ gespannt zu erwarten. Ausserdem finden wir Anzeichen dafür, dass die Händler auf die Geschehnisse an der Wall Street überreagieren; diese Überreaktion ist jedoch zu schwach, um daraus eine profitable TradingStrategie ableiten zu können.

\section{RÉSUMÉ}

Dans ce travail nous voulons savoir si les traders travaillant à la Bourse Suisse (SWX) se laissent influencer par les événements de Wall Street. Les résultats mettent en évidence que la publication de données macroéconomiques aux EtatsUnis, également d'une grande importance pour Wall Street, provoque effectivement une réaction significative. De plus, les traders à SWX semblent attendre avec impatience l'ouverture de l'échange à Wall Street à 15:30 HEC. Finalement, nous trouvons des indications qui montrent que les traders réagissent aux événements à Wall Street de manière trop prononcée. Cependant, cette réaction est trop faible pour en déduire une stratégie de trading profitable. 